\title{
English teachers' conceptualization of foreign language literacy in relation to Indonesia's Gerakan Literasi Sekolah (school literacy initiative)
}

\author{
Utami Widiati $^{1 *}$, Anik Nunuk Wulyani ${ }^{2}$, Niamika El Khoiri ${ }^{3}$, Lina Hanifiyah ${ }^{4}$, Meyga \\ Agustia Nindya $^{5}$, and Tengku Intan Suzila Tengku Sharif ${ }^{6}$ \\ 1, 2, 3, 4, 5 Department of English, Fakultas Sastra, Universitas Negeri Malang, Jalan Semarang 5, Malang, \\ East Java, Indonesia \\ ${ }^{6}$ Academy of Language Studies, Universiti Teknologi MARA Cawangan Pahang, 26400 Bandar Pusat Jengka \\ Pahang, Malaysia
}

\begin{abstract}
This study aims to explore how, in relation to Indonesia's Gerakan Literasi Sekolah (GLS School Literacy Initiative), Indonesian English teachers of secondary schools conceptualize L2 literacy in terms of linguistic and other sign systems, cognitive, sociocultural, and developmental dimensions, a model of literacy beliefs profile by Kucer (2014). The data were collected through a survey questionnaire adapted from Kucer's model, comprising 37 closedended items on conceptual understandings of foreign language literacy, presented in values of 1 to 5 Likert-scale indicating statements from strongly disagree (SD), disagree (D), neutral (N), agree (A), to strongly agree (SA). After being moderated for validity and clarity, the questionnaire was distributed to various groups and forums of English teachers through Googleform. With this convenience sampling procedure, 157 English teachers, mostly from East Java Province, Indonesia, responded to our questionnaire. The results of descriptive analyses in the forms of mean percentages portray how English teachers in our study successfully frame L2 language literacy as reflected in Kucer's dimensions, which potentially equip them with knowledge about taking part in the success of GLS implementation. They seem to understand that the core of literacy lies in the cognitive dimension, suggesting the use of literacy to express meanings, and that the expressions of meaning require linguistic literacy dimension as the vehicle. These cognitive and linguistic literacy dimensions are affected by the sociocultural literacy dimension, and the employment of the three dimensions tends to continually exist as we are experiencing new and novel events from day to day. Future research might focus on exploring how these understandings about literacy are finally realized in the classroom.
\end{abstract}

Keywords: English teachers' conceptualization; foreign/second language literacy; Gerakan Literasi Sekolah - GLS (school literacy initiative); literacy dimensions

\begin{tabular}{|ccc||}
\hline \hline First Received: & Revised: & Accepted: \\
29 November 2020 & 27 February 2021 & 22 March 2021 \\
Final Proof Received: & Published: \\
16 May 2021 & 31 May 2021 \\
\hline How to cite (in APA style): & \\
Widiati, U., Wulyani, A. N., El Khoiri, N., Hanifiyah, L., Nindya, M. A., \& Sharif, T. I. Z. T. \\
(2021). English teachers' conceptualization of foreign language literacy in relation to \\
Indonesia's Gerakan Literasi Sekolah (school literacy initiative). Indonesian Journal of \\
Applied Linguistics, 11(1), 233-244. https://doi.org/10.17509/ijal.v11i1.34586 \\
\hline
\end{tabular}

\section{INTRODUCTION}

Literacy is one of life essential skills which determine human resource quality. It appears so vital that it embraces all aspects of everyday life; a highly literate person may excel in this competitive global world. In the context of education, literacy skills are commonly used to measure students' readiness to resume their studies. Conversely, the

\footnotetext{
*Corresponding Author

Email: utami.widiati.fs@um.ac.id
} 
Indonesian students' literacy skills were found to be of a lower degree when measured by such international assessment initiatives as the Programme for International Student Assessment (PISA) and the Progress in International Reading Literacy Study (PIRLS), similar to what is happening globally as reviewed by Ganasan et al. (2020): ‘today's students' literacy achievement is unacceptably low to meet the country's needs and goals for personal and national aspirations" (p 162). Therefore, the Indonesian government has launched a national program called Gerakan Literasi Sekolah (GLS - School Literacy Initiative) through the implementation of the 2013 Curriculum. GLS program guidelines were then issued by the Ministry of Education and Culture (MEC), covering the basic principles of balancing oral and written language activities, complying with literacy pedagogy and literacy development, and taking place across curricular areas and across the school (Wiedarti \& Laksono, 2016).

MEC pilot project has involved a number of selected schools to serve as GLS implementation models in the country. A recent survey by MEC involving 6,500 Year-10 students of 34 provinces throughout the country reported positive impacts of GLS, where the literacy skills of Indonesian students have improved to 61\% (Seftiawan, 2019). The success of this central-government-initiated program is possibly due to various local supports in the form of systematically-programmed school activities to inculcate the development of school literacy culture. These include teachers' active participation in GLS implementation programs through habit-formation strategies (Pradana et al., 2017) and imposing several strategies in managing the GLS program for literacy development (Munimah, 2017). Empirical evidence of GLS policy implementation in the elementary schools has also been provided (Wulandari, 2017). Other studies related to GLS have focused on identifying supporting activities, contributing factors, and positive benefits of GLS for students (Antasari, 2017; Endaryanta, 2017; Hidayat et al., 2018; Wulandari, 2017).

In spite of the positive impacts, there have been many challenges arising from the implementation of GLS. For example, the GLS program faced at least these three serious problems: lack of reading resources, lack of teachers' knowledge and skills in dealing with literacy development, and lack of supporting facilities for the program (Huda, 2017 in Hidayat et al., 2018). Next, the knowledge and skills of teachers and headmasters need to be enhanced for further GLS implementation success (Hidayat et al., 2018). Other problems involve little support from parents and low reading interest among the students (Kurniawan et al., 2019). These studies are, however, rooted from the context of first language (L1) literacy.
Triggered by personal and professional queries, the present study focuses on the roles of English teachers in the enforcement of GLS program. As a part of the school community, English teachers' actively partaking in the development of literacy culture should also be anticipated. Yet, the questions are: Do English teachers initiate the development of foreign language literacy of their students when teachers of other subjects might be involved in the development of L1 literacy? How do English teachers contribute to the development of their students' literacy skills? Scarce evidence has been reported in this regard; meanwhile, Hidayat et al. (2018) have reported that teachers' knowledge and skills about L1 literacy development still need to be enhanced. Therefore, it seems essential to explore how English teachers perceive their roles in the development of their students' foreign language literacy. The data obtained will be beneficial as the basis for establishing school programs to develop students' foreign language literacy in the enforcement of GLS implementation.

Much literature on second language (L2) literacy has reported the impact of L1 literacy knowledge on L2 reading development (e.g., Koda, 2005, 2007; Peregoy \& Boyle, 2000). Students who are literate in their L1 tend to possess much knowledge about various aspects of reading, and this knowledge offers an experiential base for literacy development in L2. Additionally, a study by Van Gelderen et al. (2004) supported transferrable language operations across languages. When a set of language operations has been acquired in L1, they should also be available within L2 contexts.

Even though much research has substantially proven the idea of transferability of language skills from L1 to L2, literacy development does not directly show such a phenomenon (Bell, 1995). The issue of transfer between literacies is not simple because L2 literacy means working with the literacy of a different language as well as a different culture, a different matter requiring a different learning style and strategy. L1 and L2 literacies are distinct in their own ways (Mu \& Carrington, 2007). As indicated by Grabe (2009), three major sets of differences between $\mathrm{L} 1$ and $\mathrm{L} 2$ reading lie in linguistic and processing aspects, cognitive and educational aspects, and sociocultural and institutional aspects. Jiang (2011) proved that her study failed to support the previous finding that L1 literacy is an important predictor of L2 reading. Later, a study by Wahyudi (2016) reveals that different contexts of literacies have resulted in the use of different literacy practices. Admitting the complexity of literacy, Dobkowska and BrzoskoBarratt (2019) support the idea that the development of foreign language literacy should not be assumed to happen in the same way as that of L1 literacy. 
A model of literacy profiles by Kucer (2014) suggests a philosophical belief that any act of literacy is conceived as involving various dimensions; this implies that literacy is critically a multidimensional process, suggesting a philosophy adopted by GLS program, similar to the one proposed by Grabe (2009) and the one by Kalantzis and Cope (2000). Kucer's model acknowledges the complex nature of literacy that should be viewed from multiple lenses, covering both an intellectual or academic necessity and an instructional one, to be later used as a foundational basis for literacy education. Kucer (2014) further states that in order to make literacy education effective, helping students become literate should be seen as finding ways of facilitating them to learn "to effectively, efficiently, and simultaneously control the linguistic and other sign systems, cognitive, sociocultural, and developmental dimensions" (p. 5). Linguistic and other sign systems dimension refers to language systems to express meaning, whereas cognitive dimension implies "the desire of the language user to explore, discover, construct, and share meaning" (Kucer, 2014, p. 5). In other words, cognitive dimension is the central point of literacy events, being realized with the physical vehicle in the form of linguistic and other sign systems. The sociocultural dimension highlights that meaning and language are always framed by social identity and social context. The developmental dimension views literacy as a never-ending process; individuals may experience ongoing relationship with literacy resulting in developmental advancements. Individuals may continuously encounter literacy events in life which require them to use their literacy skills in new and novel ways (Kalantzis \& Cope, 2000; Kucer, 2014; Pahl \& Rowsell, 2005).

Based on those pieces of theoretical and empirical evidence, questions arise regarding English teachers' conceptualization of foreign language literacy in the Indonesian context. When English teachers do not yet have general conceptual understanding of foreign language literacy, they cannot be expected to put the literacy concepts into practice. As pointed out by Khairuddiniyah (2017), teachers' understandings and comprehension of literacy play crucial roles in the implementation of effective literacy teaching. Additionally, much literature that Novianti et al. (2020) reviewed reveals that many English teachers seem to put (critical) literacy development aside among their students because in general they have focused more on helping their students become proficient users of English. Novianti et al. (2020) further admit that developing students' (critical) literacy is a real challenge for English teachers when their teaching practice is governed by curricula and certain standards such as the one in the Indonesian context. Spurred by an enthusiasm in support of more successful GLS and, at the same time, the need for building up awareness among English teachers of L2 literacy, this present study is intended to explore how English teachers of secondary schools in the Indonesian context frame foreign language literacy in reference to Kucer's (2014) literacy profiles. Kucer's model was adopted as it covers dimensions substantially in line with the principles of GLS as well as the reading elements by Grabe (2009) and the multiliteracies by Kalantzis and Cope (2000). This study was then guided by this research question: How do Indonesian English teachers of secondary schools conceptualize L2 literacy in terms of linguistic and other sign systems, cognitive, sociocultural, and developmental dimensions?

\section{METHOD}

This study used a survey questionnaire to collect the data from English teachers of secondary schools, be they junior or senior high. Referring to Punch (2005) and Creswell (2012), the questionnaire sought factual information such as background and biographical information and knowledge and behavioral information of the English teachers as well as included measures of the teachers' conceptual understandings about foreign language literacy.

The questionnaire items were developed based on Kucer's (2014) model of literacy profiles, adjusted to the context of foreign language teaching. It consisted of 37 items covering two sections that seek different types of information: background information and literacy conceptualization. The first part was meant to record data on teaching experience and academic qualification. The second part comprised 37 closed-ended questionnaire items on conceptual understandings of foreign language literacy, presented in values of 1 to 5 Likert-scale indicating statements from strongly disagree (SD), disagree (D), neutral (N), agree (A), to strongly agree (SA). Out of these 37 items, five are concerned with understanding English teaching in the Indonesian context, whereas 32 were based on Kucer's (2014) literacy beliefs profile. The number of the questionnaire items in the original version by Kucer is 60 , but we selected items which suited our research objectives and came up with 32 questionnaire items which were then modified and adapted as necessary. These 32 items encompass eight items belonging to linguistic, ten items to cognitive, six items to sociocultural, and eight items to developmental literacy dimensions. The 37 items were then translated into Bahasa Indonesia to ensure concept clarity and to avoid misinterpretation among teachers due to their English proficiency. More detailed information about the questionnaire item distribution can be seen in Table 1 .

Before being distributed, the questionnaire was validated by two colleagues considered experts in literacy and in ELT. Revisions were made based on 
the feedback they provided. The validated questionnaire was then transformed into a Googleform (G-form) format and distributed to various accessible teachers' groups and forums within twoweek time. In this case, we followed the idea of convenience sampling (Creswell, 2012; Punch, 2005) because we relied on the advantages of using the G-form in addition to approaching the heads or coordinators of the teachers' groups and forums that we knew of to invite voluntary teacher participation in responding to our questionnaire. We did not use formal approaches through headmasters' instructing English teachers to participate; rather, we contacted groups of English teachers easy to contact and to reach as parts of the population close to hand.

Table 1

Item Distribution in the Questionnaire

\begin{tabular}{|c|c|c|c|}
\hline Questionnaire Sections & \multicolumn{3}{|c|}{ Information to Elicit } \\
\hline $\begin{array}{l}\text { I. Background } \\
\text { Information }\end{array}$ & \multicolumn{3}{|c|}{$\begin{array}{l}\text { - school level } \\
\text { - length of teaching experience } \\
\text { - qualification background }\end{array}$} \\
\hline \multirow{6}{*}{$\begin{array}{l}\text { II. Literacy } \\
\text { Conceptualization } \\
\text { (37 closed-ended } \\
\text { questionnaire items }\end{array}$} & Literacy Dimensions & Aspects & Item number \\
\hline & General introductory & $\begin{array}{l}\text { English teaching in the Indonesian context (junior } \\
\text { and senior high schools) }\end{array}$ & $1,2,3,4,5$ \\
\hline & $\begin{array}{l}\text { Linguistic and other } \\
\text { signs }\end{array}$ & $\begin{array}{l}\text { Knowledge about sounds, letters, words, } \\
\text { vocabulary, syntax, and the role of L1 }\end{array}$ & $\begin{array}{l}6,7,8,9,10 \\
11,12,13\end{array}$ \\
\hline & Cognitive & $\begin{array}{l}\text { Knowledge about reader and writer characteristics, } \\
\text { reading and writing processes, reading and writing } \\
\text { strategies, and critical thinking }\end{array}$ & $\begin{array}{l}14,15,16,17, \\
18,19,20,21, \\
22,23\end{array}$ \\
\hline & Sociocultural & $\begin{array}{l}\text { Knowledge about home culture, school culture, and } \\
\text { society culture }\end{array}$ & $\begin{array}{l}24,25,26,27, \\
28,29\end{array}$ \\
\hline & Developmental & $\begin{array}{l}\text { Knowledge about learning organization, } \\
\text { developmental stages, and learning orientation }\end{array}$ & $\begin{array}{l}30,31,32,33, \\
34,35,36,37\end{array}$ \\
\hline
\end{tabular}

After two weeks waiting, the number of returned responses from English teachers was 157. As we employed convenience sampling in collecting the data, it was not surprising that out of 157 teachers, $149(94.9 \%)$ were from various cities in our province, that is, East Java Province, and the rest $(5.1 \%)$ were from other provinces. The responses to the 37 closed-ended items from these 157 research respondents were then descriptively analyzed to find out the frequency of occurrences of each scale in each item to be then transferred into percentages. Mean percentages were calculated for each dimension category to indicate teachers' understandings of the literacy dimensions.

\section{FINDINGS AND DISCUSSION}

The research findings are presented in accordance with the literacy dimensions and then discussed in relation to the relevant literature.

\section{Background information about the research respondents}

The results of analyzing the first section of the questionnaire indicate that the 157 English teachers responding to our questionnaire comprised 106 teachers of junior high schools and 51 of senior high schools. In terms of teaching experience, the majority of the English teachers $(29.90 \%)$ have been teaching for more than twenty years, $24.20 \%$ for between 15 to 20 years, and $17.80 \%$ for between 10 to 15 years. When the percentages of these groups are put together, the data imply that our respondents are mostly of experienced English teachers, following the classification of teachers by Farrel (2012). A small number of teachers (14\%) have less-than-five-year teaching experience. Such a teacher proportion in terms of teaching experience is possibly due to the moratorium policy implemented by the Indonesian government in the last few years, as has been reported by Widiati et al. (2018).

In terms of academic qualification, our data show that 110 teachers (70\%) hold a B.Ed. in English, which suggests that by Indonesian laws they met the minimum requirements for teaching English subject. Forty-three teachers $(27.4 \%)$ hold a master's degree, whereas two teachers (1.3\%) possess a certificate to teach English and another two $(1.3 \%)$ have B.Ed. in other subjects. Our data collection process, however, did not allow us to explore further how the two teachers graduating from an undergraduate program in other fields of study eventually taught English. They might have been through the professional teacher certification so that they were eligible to teach English.

\section{English teachers' conceptualization of foreign language literacy}

The second part of the questionnaire was meant to obtain information about the teachers' conceptual understandings of foreign language literacy. Their responses to the 37 closed-ended questionnaire items are presented in the sections that follow in regard to the literacy dimension categories. 


\section{Conceptualization of the teaching context}

The questionnaire begins with five items eliciting information about the teachers' understanding of English teaching in the Indonesian context as presented in Table 2. The table reveals that on average, $50.32 \%$ teachers strongly agreed and $38.08 \%$ teachers agreed that English teaching in the Indonesian context is formally oriented towards students' attainment of certain literacy levels, functional level for junior high school students and informative level for senior high school students. These two groups being considered having the same values imply that the English teachers in our study had very good understanding of the context they are teaching. The rest of the teachers reflect $8.3 \%$ of being unsure about the context and $3.3 \%$ of not understanding the context. Being well informed with the context of teaching is likely to help teachers better prepare to teach this complex L2 (Brown \& Lee, 2015) because teaching an L2 indeed deals with a number of contextual considerations in order for teachers to sense the complexity. In other words, having good understanding of teaching context may result in better teaching activities, as can also be expected from the majority of the teachers involved in this study.

Table 2

Conceptualization of Teaching Context

\begin{tabular}{cccccc}
\hline Item & $\mathbf{1}(\mathbf{S D})$ & $\mathbf{2}(\mathbf{D})$ & $\mathbf{3}(\mathbf{N})$ & $\mathbf{4}(\mathbf{A})$ & $\mathbf{5}(\mathbf{S A})$ \\
\hline 1 & $2(1.3 \%)$ & $1(0.6 \%)$ & $7(4.5 \%)$ & $57(36.3 \%)$ & $90(57.3 \%)$ \\
2 & $1(0.6 \%)$ & $1(0.6 \%)$ & $11(7 \%)$ & $73(46.5 \%)$ & $71(45.2 \%)$ \\
3 & $0(0 \%)$ & $3(1.9 \%)$ & $7(4.5 \%)$ & $59(37.6 \%)$ & $88(56.1 \%)$ \\
4 & $2(1.3 \%)$ & $2(1.3 \%)$ & $5(3.2 \%)$ & $50(31.8 \%)$ & $98(62.4 \%)$ \\
5 & $1(0.6 \%)$ & $13(8.3 \%)$ & $35(22.3 \%)$ & $60(38.2 \%)$ & $48(30.6 \%)$ \\
\hline $\mathbf{\Sigma ( \% )}$ & $\mathbf{0 . 7 6 \%}$ & $\mathbf{2 . 5 4 \%}$ & $\mathbf{8 . 3 0 \%}$ & $\mathbf{3 8 . 0 8 \%}$ & $\mathbf{5 0 . 3 2 \%}$ \\
\hline
\end{tabular}

When the data about general introductory understanding were examined further, the teachers' responses to item number five were quite unique compared to those to the other four questionnaire items showing similar trends in terms of agreement. The item asks whether the teachers were of the opinion that literacy in L2 was similar to literacy in L1, and their responses indicate that $30.60 \%$ of them strongly agreed and $38.20 \%$ agreed. Only few teachers admitted that L2 literacy was not the same as L1 literacy, reflected in $.60 \%$ stating strong disagreement and $8.30 \%$ disagreement. These two categories being put together imply that in total, only $8.90 \%$ teachers (14 out of 157) had the understanding that L2 literacy should be considered different from L1 literacy. It is interesting to note that quite many teachers, as many as 35 teachers $(22.30 \%)$ as shown in Table 2, seemed to be in doubt about the issue as indicated by their selecting the neutral scale. Such distribution of the teachers' responses to item number 5 designates that a number of English teachers under our study may have been indecisive about how to view L1 and L2 literacy skills, whether to consider them to represent universal cognitive capacities emphasizing mental operations performed, thus following the proposition of transferability of L1 literacy skills to L2 literacy skills (Koda, 2005, 2007; Peregoy \& Boyle, 2000; Ridgway, 2003; Van Gelderen et al., 2004), or to regard them as distinct (Dobkowska \& Brzosko-Barratt, 2019; Jiang, 2011; Mu \& Carrington, 2007; Wahyudi, 2016). In regard to the limitations of our research instrument concerning this issue, future research might be geared towards utilizing additional research instruments to portray
English teachers' views about their teaching context more comprehensively.

\section{Conceptualization of the linguistic and other signs literacy dimension}

The next findings presented in Table 3 refer to the linguistic and other signs literacy dimension. Table 3 shows that on average, $39.42 \%$ teachers strongly agreed and $32.86 \%$ agreed on the view that language is essential to convey meaning. Our raw data about strong agreement and agreement regarding this dimension category reflect quite similar trends of percentages on knowledge about sounds (number 6 and number 7), knowledge about letters (number 8 and number 9), knowledge about words and vocabulary (number 12 and number 13), and knowledge about syntax (number 10), but sightlydifferent percentage on knowledge about the role of L1 (number 11).

More specifically, concerning knowledge about sounds, Table 3 suggests that the majority of the teachers' responses to items number 6 and number 7 indicate their understanding that sound system was essential in English teaching. These teachers may have admitted the importance of phonological perception for listening and intelligible pronunciation for speaking, as highlighted by Saville-Troike (2006). Such research findings seem in line with the argument that considering the function of a language as a vehicle to express meanings, English teachers are supposed to introduce the language system starting from the sound system. Therefore, English teachers need to facilitate their learners to understand well how the system operates, as pointed out by Kucer (2014) and Scrivener (2011). 
Table 3

Linguistic and Other Signs Literacy Dimension

\begin{tabular}{rrrrrc}
\hline \multicolumn{1}{r}{ Item } & $\mathbf{1}(\mathbf{S D})$ & \multicolumn{1}{c}{$\mathbf{2}(\mathbf{D})$} & $\mathbf{3}(\mathbf{N})$ & $\mathbf{4}(\mathbf{A})$ & $\mathbf{5}(\mathbf{S A})$ \\
\hline 6 & $3(1.9 \%)$ & $15(9.6 \%)$ & $24(15.3 \%)$ & $54(34.4 \%)$ & $61(38.9 \%)$ \\
7 & $2(1.3 \%)$ & $8(5.1 \%)$ & $19(12.1 \%)$ & $69(43.9 \%)$ & $59(37.6 \%)$ \\
8 & $7(4.5 \%)$ & $16(10.2 \%)$ & $33(21 \%)$ & $59(37.6 \%)$ & $42(26.8 \%)$ \\
9 & $6(3.8 \%)$ & $25(15.9 \%)$ & $43(27.4 \%)$ & $43(27.4 \%)$ & $40(25.5 \%)$ \\
10 & $5(3.2 \%)$ & $14(8.9 \%)$ & $32(20.4 \%)$ & $52(33.1 \%)$ & $54(34.4 \%)$ \\
11 & $16(10.2 \%)$ & $29(18.5 \%)$ & $35(22.3 \%)$ & $47(29.9 \%)$ & $30(19.1 \%)$ \\
12 & $0(0 \%)$ & $0(0 \%)$ & $5(3.2 \%)$ & $39(24.8 \%)$ & $113(72 \%)$ \\
13 & $1(0.6 \%)$ & $3(1.9 \%)$ & $7(4.5 \%)$ & $50(31.8 \%)$ & $96(61.1 \%)$ \\
\hline $\mathbf{\Sigma ( \% )}$ & $\mathbf{3 . 1 8 \%}$ & $\mathbf{8 . 7 6 \%}$ & $\mathbf{1 5 . 7 8 \%}$ & $\mathbf{3 2 . 8 6 \%}$ & $\mathbf{3 9 . 4 2 \%}$ \\
\hline
\end{tabular}

In addition to knowledge about sounds, knowledge about letters appears necessary. The responses of the English teachers under this study to items number 8 and number 9 stipulate similar trends, designating that the English teachers in this study seem to perceive English spelling crucial. Such perceptions may have been stimulated by their factual knowledge that English does not have straightforward correspondences between spelling and pronunciation, a fact about English that is likely to lead to potential difficulties (Saville-Troike, 2006; Scrivener, 2011). According to Bassetti (2012), English belongs to a language that has a low level of phonological transparency; the same sound is not always spelled with the same letters, or the same letter is not always pronounced with the same sound, and even correspondences for vowels are more complex than those for consonants. Bassetti (2012) further argues that the level of phonological transparency has effects on learners' reading and spelling processes as well as literacy acquisition, challenges that might have also been perceived by our research subjects.

The next point from Table 3 that needs highlighting is that almost all of the teachers agreed or strongly agreed that vocabulary is crucial to comprehension as well as literacy development, as can be seen from their responses to questionnaire items number 12 and 13 . This understanding is in line with what Kucer $(2014$, p. 190) states, "it is well established in the research literature that there is a relationship between word knowledge and comprehension." One of the core components in language proficiency is vocabulary knowledge as it relates to literacy development (Leppänen et al., 2008). What English teachers need further is exploring pieces of empirical evidence aimed at informing approaches to the development of overall vocabulary size for the purpose of supporting L2 reading comprehension, such as the one by Masrai (2019). In addition to acknowledging that vocabulary size is one of the determinant factors for reading achievement in the L2 context, English teachers should also question what type of vocabulary is more instrumental in comprehension, high-, mid-, or low-frequency words.

Finally, it is worth noting at this point that an interesting phenomenon from our raw data was found in the teachers' responses to questionnaire item number 11 , an item eliciting their views about the role of L1 in L2 learning. The distribution of their responses quite evenly spreading from strong disagreement to strong agreement imply perceived understandings of learners' L1 as the cause of their difficulties learning L2. Such perceptions could have been influenced by the teachers' understanding of Contrastive analysis (CA) which took the position that L1 was the villain in L2 learning (Dulay et al., 1982), whereas recent years have witnessed how learners' L1 is placed in a more respectable and valuable position. It is very likely that those teachers were influenced by the Behavioristic View when they were taking their pre-service teacher education, and we speculate this since our data indicate that the majority of our research subjects had more than 10year teaching experience. The current practice, in contrast, suggests that instead of blaming L1 as the cause of learners' difficulties, English teachers should view learners' L1 as an invaluable asset; L1 needs to be employed effectively and judiciously (Mohebbi \& Alavi, 2014). As also highlighted by Novianti et al. (2020), EFL instructions can in fact empower students to see their status as non-native speakers and their bilingualism or multilingualism as an advantage instead of a disadvantage in learning about foreign language and literature critically. Future researchers might be interested in surveying English teachers' attitudes towards L1 in the context of English teaching in Indonesia and then proposing possible ways of helping them design and implement foreign language literacy teaching strategies in such a context to make an optimum use of students' L1.

\section{Conceptualization of the cognitive literacy dimension}

Table 4 presents findings of cognitive literacy dimension, a dimension dealing with the desire to express meaning, more specifically according to Kucer (2014) "to explore, discover, construct, and share meaning" ( $p$ 5), comprising "the mental processes, strategies, or procedures the individual engages to construct meaning" ( $p$ 109). Our data show that overall, the English teachers agreed $(38.36 \%)$ and strongly agreed $(42.73 \%)$ that the cognitive processes of meaning making are 
influenced by knowledge about reader and writer characteristics, knowledge about reading and writing processes, knowledge about reading and writing strategies, and the importance of critical thinking. The cognitive literacy dimension can be regarded as the psycholinguistic extension of the linguistic literacy dimension because meaning making involves transactional interactions between mind (cognition) and the language (Kucer, 2014, p 111).

Table 4

\begin{tabular}{crrrrr} 
Cognitive Literacy Dimension & \multicolumn{1}{l}{} \\
\hline Item & $\mathbf{1}(\mathbf{S D})$ & $\mathbf{2}(\mathbf{D})$ & $\mathbf{3}(\mathbf{N})$ & $\mathbf{4}(\mathbf{A})$ & $\mathbf{5}(\mathbf{S A})$ \\
\hline 14 & $0(0 \%)$ & $4(2.5 \%)$ & $13(8.3 \%)$ & $61(38.9 \%)$ & $79(50.3 \%)$ \\
15 & $2(1.3 \%)$ & $3(1.9 \%)$ & $17(10.8 \%)$ & $71(45.2 \%)$ & $64(40.8 \%)$ \\
16 & $1(0.6 \%)$ & $1(0.6 \%)$ & $13(8.3 \%)$ & $60(38.2 \%)$ & $82(52.2 \%)$ \\
17 & $2(1.3 \%)$ & $8(5.1 \%)$ & $28(17.8 \%)$ & $61(38.9 \%)$ & $58(36.9 \%)$ \\
18 & $0(0 \%)$ & $5(3.2 \%)$ & $26(16.6 \%)$ & $62(39.5 \%)$ & $64(40.8 \%)$ \\
19 & $4(2.5 \%)$ & $16(10.2 \%)$ & $39(24.8 \%)$ & $59(37.6 \%)$ & $39(24.8 \%)$ \\
20 & $0(0 \%)$ & $4(2.5 \%)$ & $19(12.1 \%)$ & $75(47.8 \%)$ & $59(37.6 \%)$ \\
21 & $10(6.4 \%)$ & $28(17.8 \%)$ & $42(26.8 \%)$ & $53(33.8 \%)$ & $24(15.3 \%)$ \\
22 & $0(0 \%)$ & $1(0.6 \%)$ & $6(3.8 \%)$ & $52(33.1 \%)$ & $98(62.4 \%)$ \\
23 & $0(0 \%)$ & $0(0 \%)$ & $5(3.2 \%)$ & $48(30.6 \%)$ & $104(66.2 \%)$ \\
\hline $\mathbf{\Sigma}(\%)$ & $\mathbf{1 . 2 2 \%}$ & $\mathbf{4 . 4 4 \%}$ & $\mathbf{1 3 . 2 5 \%}$ & $\mathbf{3 8 . 3 6 \%}$ & $\mathbf{4 2 . 7 3 \%}$ \\
\hline
\end{tabular}

When the responses to individual questionnaire items were examined further, our data mirror quite a high degree of commonalities in terms of the trends of the percentages, from knowledge about reader and writer characteristics (items number 14 and 15), knowledge about reading and writing processes (items number 16 and 17), knowledge about reading and writing strategies (items number 18 and 20, but not items number 19 and 21), to knowledge about critical thinking (items number 22 and 23). Such findings reflect that the English teachers in this present study hold good understandings of readerand-writer as well as reading-and-writing connections. As Kucer (2014) has cited, there seems a contractual agreement between readers and writers, a contract that requires writers to produce texts as informatively as possible for readers to have complete understandings of the texts. In particular, in the context of L2 acquisition, Harklau's (2002) observation revealed that written language functions as more readily available sources for language input than the face-to-face student-teacher and studentstudent interactions; even in a broader context of curriculum implementation, reading and writing at schools play a central role in communication and transmission of subject matter. In line with this, Brown and Lee (2015) underscore that the goals of teaching reading or teaching writing will be best attained by capitalizing on reading-writing connections. Furthermore, the English teachers in our study noted the need for paying attention to the strategies of efficient reading as well as effective writing, as can be seen from their responses to questionnaire items number 18 and 20. According to Brown and Lee (2015), much research evidence supports a viable theory that "instructed second language acquisition can hardly be sustainable without a solid component of strategic competence" (p 393). When strategic competence and critical thinking are embedded within the development of reading and writing skills, Brown and Lee (2015, p. 575) assure that teachers can realize the charge of the responsibility of helping students seize their agency through language, an attribute critical to their success in learning a new language (Li, 2020). Much research has provided evidence about the importance of encouraging students to become agents of learning "who are aware of their actions and behaviors and take control over their learning processes" (Brown \& Lee, 2015, p. 89). There then appears some close relationship between literacy learning and learning autonomy (Widiati, 2010).

It is interesting to note here that the data related to items number 19 and 21 reflect different distributions of percentages. Item number 19 seeks for teachers' opinions about whether readers or writers need to slow down their reading or writing process when confronted with problems. Table 4 shows that quite a number of teachers $(24.80 \%)$ were in doubt about this statement, whereas the majority of them agreed (37.60\%) or strongly agreed $(24.80 \%)$ with the statement. Our speculative interpretation to such responses is that these English teachers might not have been well informed about the need for drawing attention to the employment of various strategies as approaches to dealing with reading or writing problems, instead of merely slowing down the reading or writing activities. It seems then necessary to equip English teachers with some conceptual as well as practical knowledge about strategy-based instruction which enables their students to learn how to learn, that is, students "become autonomous through becoming aware of their own strengths and weaknesses and taking action in the form of strategic involvement in learning" (Brown \& Lee, 2015, p. 51). Implied in the concepts of autonomy and agency is the centrality of students because the success of learning any skill requires a certain degree of their strategic investment in terms of time and effort from learners. 
Teachers thus need to build into their pedagogy ways of helping their students realize the importance of such strategic autonomy or agency, an issue worth exploring for future research. The need for employing appropriate strategies was evidenced by Ridgway (2003), who has identified that many students might possess the linguistic proficiency to deal with a text but are unable to do so because they are approaching it in an inappropriate way. Literacy teaching according to Ridgway (2003) needs to be made more explicit in order to help students cope with such a problem.

Item number 21 questions the teachers' views about whether the activities of re-reading or rewriting reflect inefficient processes. The data in Table 4 indicate that $26.80 \%$ were dubious about the statement, whereas $33.80 \%$ agreed and $15.30 \%$ strongly agreed with the statement. When added up, those responses imply that the English teachers might not have been familiar yet with the processoriented approaches in teaching, a teaching philosophy that acknowledges that reading or writing processes are not linear, but recursive. As Brown and Lee (2015) suggest, students need to be carefully led through appropriate stages, meaning that students' experiencing going back and forth during the reading and writing processes should be considered normal. In other words, activities of rereading or re-writing do not necessarily parallel inefficiencies. Kucer (2014) in this case states that in many classrooms, the process-oriented philosophy has become commonplace through the implementation of reader response groups and writing conferences. Future research might be oriented towards exploring teachers' conceptual knowledge about the process-oriented teaching philosophy and documenting empirical data about their translating the knowledge into practice.

\section{Conceptualization of the sociocultural literacy dimension}

Table 5 shows findings about the English teachers' conceptualization of the sociocultural literacy dimension. The teachers' responses to all the items under this dimension suggest similar patterns, as can be seen from the data of the mean percentages, $37.70 \%$ of agreement and $34.09 \%$ of strong agreement. These figures designate some understanding among our research subjects about the power literacy has in addressing social and cultural complexity, which is in line with Kucer's (2014) model of literacy dimensions. The model stipulates that literacy is a social act, that is, a set of social practices which capture social events, more than merely individual acts of meaning making and language use. This understanding necessitates today's teachers' showing their students how literacy is defined and realized as social practices by various communities, facilitating them to become aware that any person is in fact a member of a society; teachers are supposed to conceptualize "the mind as being embedded within the society" as Vygotsky (1978 in Kucer, 2014, p. 230) proposed. In other words, literacy is not simply individual acts of language and cognition but also patterned acts and behaviors of a society (Kucer, 2014). When linguistic and cognitive literacy dimensions can be seen as having decontextualized commonalities or universals, the sociocultural dimension of literacy should be practiced in regard to particular social configurations. The study by Wahyudi (2016) provided evidence about ways to understand and expand knowledge on literacy as social practices by exploring the experiences of an ESL student in Australia, that is, how literacy was exercised both in the home countryand in Australia. One of Wahyudi's findings proves that home and school literacy practices mutually support each other.

Table 5

Sociocultural Literacy Dimension

\begin{tabular}{cccccc}
\hline \multicolumn{1}{l}{ Sociocultural Literacy Dimension } \\
\hline Item & $\mathbf{1}(\mathbf{S D})$ & $\mathbf{2}(\mathbf{D})$ & $\mathbf{3}(\mathbf{N})$ & $\mathbf{4}(\mathbf{A})$ & $\mathbf{5}(\mathbf{S A})$ \\
\hline 24 & $1(0.6 \%)$ & $3(1.9 \%)$ & $17(10.8 \%)$ & $62(39.5 \%)$ & $74(47.1 \%)$ \\
25 & $9(5.7 \%)$ & $31(19.7 \%)$ & $43(27.4 \%)$ & $53(33.8 \%)$ & $21(13.4 \%)$ \\
26 & $3(1.9 \%)$ & $14(8.9 \%)$ & $40(25.5 \%)$ & $54(34.4 \%)$ & $46(29.3 \%)$ \\
27 & $9(5.7 \%)$ & $28(17.8 \%)$ & $45(28.7 \%)$ & $49(31.2 \%)$ & $26(16.6 \%)$ \\
28 & $0(0 \%)$ & $6(3.8 \%)$ & $8(5.1 \%)$ & $59(37.6 \%)$ & $84(53.5 \%)$ \\
29 & $0(0 \%)$ & $1(0.6 \%)$ & $8(5.1 \%)$ & $78(49.7 \%)$ & $70(44.6 \%)$ \\
\hline $\mathbf{\Sigma ( \% )}$ & $\mathbf{2 . 3 2 \%}$ & $\mathbf{8 . 7 9 \%}$ & $\mathbf{1 7 . 1 0} \%$ & $\mathbf{3 7 . 7 0 \%}$ & $\mathbf{3 4 . 0 9 \%}$ \\
\hline
\end{tabular}

Our findings as presented in Table 5 have added data about English teachers' acknowledging how literacy is framed within a society. More specifically, the responses reflect some conceptualization of building up knowledge about home culture, as elicited from questionnaire items number 24, 27, and 28, knowledge about school culture, from items number 25 and 29 , and knowledge about society culture, from item number 26. Such conceptualization brings impacts on education that acknowledges an increased sensitivity to the range of socially based experiences and meanings that students bring to the classroom. Teachers seem to be challenged to ensure a more diverse representation of knowledges in the curriculum and more equitable access to these knowledges. This kind of sensitivity to diversity can be explored through the provision of culturally responsive pedagogy and literacy teaching, approaches that teachers may employ in order to put 
the home culture, the school culture, and the society culture in harmony. Nakaya (2018) emphasized the importance of culturally responsive instruction in developing students' positive racial attitudes and eventually cultivating national identity. This pedagogical philosophy is indeed vital considering that Indonesia is a very multicultural nation. Realizing the strong connection between home, school, and society cultures through multicultural education might be a real challenge for many
English teachers, as also highlighted by Ariani and Widiati (2017).

\section{Conceptualization of the developmental literacy dimension}

The last dimension concerns developmental literacy. Typically, development continues throughout the course of life, and the three dimensions of literacy discussed previously are encountered and used in novel ways within day-to-day events.

Table 6

Developmental Literacy Dimension

\begin{tabular}{ccrrrc}
\hline Item & $\mathbf{1}(\mathbf{S D})$ & $\mathbf{2}(\mathbf{D})$ & $\mathbf{3}(\mathbf{N})$ & $\mathbf{4}(\mathbf{A})$ & $\mathbf{5}(\mathbf{S A})$ \\
\hline 30 & $1(0.6 \%)$ & $5(3.2 \%)$ & $21(13.4 \%)$ & $60(38.2 \%)$ & $70(44.6 \%)$ \\
31 & $7(4.5 \%)$ & $14(8.9 \%)$ & $40(25.5 \%)$ & $51(32.5 \%)$ & $45(28.7 \%)$ \\
32 & $0(0.0 \%)$ & $1(0.6 \%)$ & $9(5.7 \%)$ & $64(40.8 \%)$ & $83(52.9 \%)$ \\
33 & $2(1.3 \%)$ & $0(0.0 \%)$ & $13(8.3 \%)$ & $45(28.7 \%)$ & $97(61.8 \%)$ \\
34 & $1(0.6 \%)$ & $6(3.8 \%)$ & $20(12.7 \%)$ & $65(41.4 \%)$ & $65(41.4 \%)$ \\
35 & $1(0.6 \%)$ & $5(3.2 \%)$ & $16(10.2 \%)$ & $71(45.2 \%)$ & $64(40.8 \%)$ \\
36 & $0(0.0 \%)$ & $1(0.6 \%)$ & $8(5.1 \%)$ & $65(41.4 \%)$ & $83(52.9 \%)$ \\
37 & $5(3.2 \%)$ & $15(9.6 \%)$ & $42(26.8 \%)$ & $56(35.7 \%)$ & $39(24.8 \%)$ \\
\hline $\mathbf{\Sigma ( \% )}$ & $\mathbf{1 . 3 5 \%}$ & $\mathbf{3 . 7 4 \%}$ & $\mathbf{1 3 . 4 5 \%}$ & $\mathbf{3 7 . 9 8 \%}$ & $\mathbf{4 3 . 4 8 \%}$ \\
\hline
\end{tabular}

The findings presented in Table 6 suggest common trends of responses for all the questionnaire items, with the mean percentage of $37.98 \%$ of agreement and $43.48 \%$ strong agreement. This developmental literacy dimension includes teachers' knowledge about learning organization, developmental stages, and learning orientation. When the raw data were examined further, however, items number 31 and 37 were responded in a doubtful way by our respondents, as indicated respectively by $25.50 \%$ and $26.80 \%$ of neutral value. Questionnaire item number 31 deals with the use of immediate teacher feedback in stimulating the students' literacy development, and the percentage of responses $(25.50 \%)$ implies these teachers' hesitance about the benefits of their feedback. In fact, as Brown and Lee (2015) have reviewed, much research reveals that quality and quantity of feedback do matter in the eventual attainment of learner competence. What is needed is then how to enable teachers to provide supportive, encouraging, and affirming feedback so that a positive affective classroom atmosphere can be established, and students will feel more motivated to continuously make attempts to become successful. Item number 37 concerns a statement that students' literacy development is dependent upon teachers' literacy competence. The percentage $(26.80 \%)$ reflects that these teachers were not sure about their role as a model for their students' literacy development. It seems necessary to continuously remind teachers of how their competence affects learners. In short, teachers and students need to sustain themselves to continue "the long and demanding process of learning language (Kucer, 2014, p. 287).

To put it in a nutshell, regarding the four literacy dimensions, our research findings manage to portray how English teachers in our study successfully frame L2 language literacy in terms of linguistic and other sign systems, cognitive, sociocultural, and developmental dimensions, a literacy model by Kucer (2014), principally in line with the one by Grabe (2009) and Kalantzis and Cope (2000) and adopted by GLS program. Those teachers seem to understand that the core of literacy lies in the cognitive dimension, suggesting the use of literacy to express meanings, and that the expressions of meaning require linguistic literacy dimension as the vehicle. Besides, these cognitive and linguistic literacy dimensions are affected by the sociocultural literacy dimension, implying that meaning is expressed, and language is used, differently by different people for different purposes. The employment of the three dimensions tends to continually exist as we are experiencing new and novel events from day to day, indicating the evidence of the developmental literacy dimension. Possessing such L2 conceptualization should become an asset for these English teachers to initiate taking part in the implementation of GLS at schools. However, our study did not examine how this conceptualization of L2 literacy was translated into practice in the classroom or at school. As Novianti et al. (2020) identified, many English teachers are discouraged from implementing literacy teaching because they still have to deal with other challenging classroom- or curriculum-related issues. For this reason, Novianti et al. (2020) proposed a classroom-based framework for literacy practice that accommodates promoting the development of language competence as well as (critical) literacy skills, the effectiveness and the practicality of which still need investigating. 


\section{CONCLUSIONS}

This survey study has provided empirical evidence about how English teachers in our study successfully conceptualize L2 language literacy in terms of linguistic and other sign systems, cognitive, sociocultural, and developmental dimensions. They own some understanding that cognitive dimension is the core of literacy, meaning that literacy is used to express meanings, and that the expressions of meaning need linguistic literacy dimension as the tool. These cognitive and linguistic literacy dimensions are affected by the sociocultural literacy dimension as different people express meaning and use language differently for different purposes. The employment of the three dimensions tends to continually exist as new situations are experienced, reflecting the developmental literacy dimension. Equipped with such L2 conceptualization, English teachers should start initiating taking part in the implementation of GLS at schools. However, our study did not examine how this conceptualization of L2 literacy was translated into practice in the classroom or at school. A classroom-based framework for literacy proposed by Novianti et al. (2020) can be implemented so that its effectiveness and the practicality can be empirically measured. The teaching of literacy should be backed up with a developmentally appropriate curriculum and instruction that promote the attainment of both language proficiency and literacy skills.

\section{ACKNOWLEDGEMENTS}

We are grateful to the two anonymous reviewers and the editors for their insightful comments on this manuscript, which is based on a research study conducted in 2020 under the funding from the Research and Community Service Unit of Universitas Negeri Malang, Indonesia, with the contract document No. 4.3.653/UN32.14.1/LT/2020.

\section{REFERENCES}

Antasari, I. W. (2017). Implementasi gerakan literasi sekolah tahap pembiasaan di MI Muhammadiyah Gandatapa Sumbang Banyumas [GLS implementation through habituation at Muhammadiyah Gandatapa primary school]. Jurnal Libria, 9(1), 13-26. https://jurnal.arraniry.ac.id/index.php/libria/article/view/1680

Ariani, M., \& Widiati, U. (2017). Multicultural education and pragmatics instruction in EFL classroom to win the learners' right to learn in the global world. Proceedings of the $10^{\text {th }}$ International Conference Revisiting English Language Teaching, Literature and Translation in the Borderless World: My world, Your World, Whose World? (pp. 154162).
Bassetti, B. (2012). Sound and spelling. In C. A. Chapelle (Ed.), The encyclopedia of applied linguistics (pp. 5312-5317). Wiley-Blackwell.

Bell, J. S. (1995). The relationship between L1 and L2 literacy: Some complicating factors. TESOL Quarterly, 29(4), 687-704. https://doi.org/10.2307/3588170

Brown, H. D., \& Lee, H. (2015). Teaching by principles: An interactive approach to language pedagogy (4th ed.). Pearson Education, Inc.

Creswell, J. W. (2012). Educational research: Planning, conducting, and evaluating quantitative and qualitative research (4th ed.). Pearson.

Dobkowska, J., \& Brzosko-Barratt, K. (2019). Exploring teacher literacy conceptualizations as opportunity for knowledge transfer and collaboration. A paper presented at the $44^{\text {th }}$ Annual Conference of the Association of Teacher Education in Europe, Bath UK, 13-16 August.

Dulay, H., Burt, M., \& Krashen, S. (1982). Language two. Oxford University Press.

Endaryanta, E. (2017). Implementasi program gerakan literasi sekolah di SD Kristen Kalam Kudus dan SD Muhammadiyah Suronatan [GLS implementation at Kalam Kudus Christian primary school and at Muhammadiyah Suronatan primary school]. Jurnal Kebijakan Pendidikan, 6(7), 732-744. http://eprints.uny.ac.id/id/eprint/53228

Farrell, T. S. C. (2012). Novice-service language teacher development: Bridging the gap between preservice and in-service education and development. TESOL Quarterly, 46(3), 435-449. https://doi.org/10.1002/tesq.36

Ganasan, M. J., Razak, N. A., \& Jamal, M. (2020). Malaysian high schoolers' reading literacy performance: Trends and patterns across states. Indonesian Journal of Applied Linguistics, 10(1), 161-172. https://doi.org/10.17509/ijal.v10i1.25031

Grabe, W. (2009). Reading in a second language: Moving from theory to practice. Cambridge University Press.

Harklau, L. (2002). The role of writing in classroom second language acquisition. Journal of Second Language Writing, 11, 329-350. https://doi.org/10.1016/S1060-3743(02)000917

Hidayat, M. H., Basuki, I. A., \& Akbar, S. (2018). Gerakan literasi sekolah di sekolah dasar [GLS implementation at primary schools]. Jurnal Pendidikan: Teori, Penelitian, dan Pengembangan, 3(6), 810-817. http://journal.um.ac.id/index.php/jptpp/article/ view/11213/5360

Jiang, X. (2011). The role of first language literacy and second language proficiency in second 
language reading comprehension. The Reading Matrix, 11(2), 177-90.

https://readingmatrix.com/articles/april_2011/ji ang.pdf

Kalantzis, M., \& Cope, B. (2000). Multiliteracies literacy learning and the design of social future. Routledge

Khairuddiniyah. (2017). The implementation of literacy strategies in teaching English by the English teacher at MAN Insan Cindekia Padang Pariaman. English Education: Jurnal Tadris Bahasa Inggris, 10(2), 242-257. http://ejournal.radenintan.ac.id/index.php/ENG EDU/article/view/1748

Koda, K. (2005). Insights into second language reading: A cross-linguistic approach. Cambridge University Press.

Koda, K. (2007). Reading and language learning: Crosslinguistic constraints on second language reading development. In K. Koda (Ed.), Reading and language learning (pp. 1-44). Wiley Online Library.

Kucer, S. B. (2014). Dimensions of literacy: A conceptual base for teaching reading and writing in school settings (4th ed.). Routledge.

Kurniawan, A. R., Chan, F., Abdurrohim, M., Wanimbo, O., Putri, N. H., Intan, F. M., \& Samosir, W. L. S. (2019). Problematika guru dalam melaksanakan gerakan literasi di kelas IV sekolah dasar [Teachers' problems in implementing GLS at primary school]. EduStream: Jurnal Pendidikan Dasar, 3(2), 31-37. https://journal.unesa.ac.id/index.php/jpd/article /view/6390

Leppänen, U., Aunola, K., Niemi, P., \& Nurmi, J. E. (2008). Letter knowledge predicts fourth grade reading fluency and reading comprehension. Learning and Instruction, 18, 548-564. https://doi.org/10.1207/s1532799xssr1001_2

Li, G. (2020). Principles for developing learner agency in language learning in a new eduscape with COVID-19. Language Learning, 5, 3040.

https://m.fx361.com/news/2020/0601/6719504 .html

Masrai, A. (2019). Vocabulary and reading comprehension revisited: Evidence for high-, mid-, and low-frequency vocabulary knowledge. SAGE Open, 9(2), 1-13. https://doi.org/10.1177\%2F215824401984518 2

Mohebbi, H., \& Alavi, S.M. (2014). An investigation into teachers' first language use in a second language learning classroom context: A questionnaire-based study. Bellaterra Journal of Teaching \& Learning Language \& Literature, 7(4), 57-73. https://revistes.uab.cat/jtl3/article/download/v7 -n4-mohebbi-alavi/539-pdf-en
Mu, J., \&. Carrington, S. (2007). An investigation of three Chinese students' English writing strategies. TESL-EJ, 11(1), 1-23. https://eric.ed.gov/?id=EJ1064994

Munimah. (2017). Manajemen program literasi dalam meningkatkan minat baca siswa (studi multi kasus pada SD dan MTs di Kabupaten Pasuruan [Literacy program management in enhancing students' reading interest (multi case study at elementary schools and Islamic junior high schools in Pasuruan regency] (Unpublished master's thesis). Universitas Negeri Malang, Indonesia.

Nakaya, A. (2018). Overcoming ethnic conflict through multicultural education: The case of West Kalimantan, Indonesia. International Journal of Multicultural Education, 20(1), 118-137. http://dx.doi.org/10.18251/ijme.v20i1.1549

Novianti, N., Thomas, A., \& To, V. (2020). Addressing challenges in the practice of critical literacy in EFL classrooms: A new framework. Indonesian Journal of Applied Linguistics, 10(1), 206-217. https://doi.org/10.17509/ijal.v10i1.25049

Pahl, K., \& Rowsell, J. (2005). Literacy and education. Paul Chapman Publishing.

Peregoy, S. F., \& Boyle, O. F. (2000). English learners reading English: What we know, what we need to know. Theory into Practice, 39(4), 237-247. https://doi.org/10.1207/s15430421tip3904_7

Pradana, B. H., Fatimah, N., \& Rochana, T. (2017). Pelaksanaan gerakan literasi sekolah sebagai upaya membentuk habitus literasi siswa di SMA Negeri 4 Magelang [GLS implementation through habituation at SMA Negeri 4 Magelang]. Solidarity, 6(2), 167-179. http://lib.unnes.ac.id/id/eprint/31959

Punch, K. F. (2005). Introduction to social research: Quantitative and qualitative approaches (2nd ed.). SAGE Publications Ltd.

Ridgway, T. (2003). Literacy and foreign language reading. Reading in a Foreign Language, 15(2), 117-129. https://scholarspace.manoa.hawaii.edu/bitstrea m/10125/66775/1/15_2_10125_66775_ridgwa y.pdf

Saville-Troike, M. (2006). Introducing second language acquisition. Cambridge University Press.

Scrivener, J. (2011). Learning teaching: The essential guide to English language teaching (3rd ed.). Macmillan Education

Seftiawan, D. (2019). Hasil penelitian Kemendikbud, kemampuan literasi siswa Indonesia membaik [Ministry's research results, Indonesian students' literacy competence is improving]. Retrieved from https://www.pikiran-rakyat.com/pendidikan/pr- 
01310964/hasil-penelitian-kemendikbudkemampuan-literasi-siswa-indonesia-membaik Van Gelderen, A., Schoonen, R., de Glopper, K., Hulstjn, J., Simis, A., Snellings, P., \& Stevenson, M. (2004). Linguistic knowledge, processing speed, and metacognitive knowledge in first- and second-language reading comprehension: A componential analysis. Journal of Educational Psychology, 96, 19-30.

https://doi.apa.org/doi/10.1037/00220663.96.1.19

Wahyudi, R. (2016). Second language literacy practices: A case study of a Chinese student in Australia. TEFLIN Journal, 27(1), 101-125. http://dx.doi.org/10.15639/teflinjournal.v27i1/ 101-125

Widiati, U. (2010). Pembelajaran kemahirwacanaan (literacy learning) untuk mengembangkan kemandirian belajar (learning autonomy) [Literacy learning for the development of learning autonomy]. A paper presented at the Professorship Inauguration, Universitas Negeri Malang, 16 December.

Widiati, U., Suryati, N., \& Hayati, N. (2018). Unraveling the challenges of Indonesian novice teachers of English. Indonesian Journal of Applied Linguistics, 7(3), 621 - 629. https://doi.org/10.17509/ijal.v7i3.9824

Wiedarti, P., \& Laksono, K. (2016). Panduan gerakan literasi sekolah di sekolah dasar [Guide to the school literacy movement in elementary schools]. Direktorat Jenderal dan Menengah Kementerian Pendidikan dan Kebudayaan

Wulandari, R. (2017). Implementasi kebijakan gerakan literasi sekolah di Sekolah Dasar Islam Terpadu Lukman Al Hakim Internasional [GLS policy implementation at Islamic Integrated Lukman Hakim primary school]. Jurnal Kebijakan Pendidikan, 6(3), 319-330. https://eprints.uny.ac.id/48717/ 